\title{
Alterations in the ribosomal machinery in cancer and hematologic disorders
}

\author{
Niraj Shenoy, Rachel Kessel, Tushar D Bhagat, Sanchari Bhattacharyya, Yiting Yu, Christine Mcmahon and
} Amit Verma

\begin{abstract}
Ribosomes are essential components of the protein translation machinery and are composed of more than 80 unique large and small ribosomal proteins. Recent studies show that in addition to their roles in protein translation, ribosomal proteins are also involved in extra-ribosomal functions of DNA repair, apoptosis and cellular homeostasis. Consequently, alterations in the synthesis or functioning of ribosomal proteins can lead to various hematologic disorders. These include congenital anemias such as Diamond Blackfan anemia and Shwachman Diamond syndrome; both of which are associated with mutations in various ribosomal genes. Acquired uniallelic deletion of RPS14 gene has also been shown to lead to the $5 q$ syndrome, a distinct subset of MDS associated with macrocytic anemia. Recent evidence shows that specific ribosomal proteins are overexpressed in liver, colon, prostate and other tumors. Ribosomal protein overexpression can promote tumorigenesis by interactions with the p53 tumor suppressor pathway and also by direct effects on various oncogenes. These data point to a broad role of ribosome protein alterations in hematologic and oncologic diseases.
\end{abstract}

Keywords: Ribosome, MDS, Anemia

\section{Introduction}

Eukaryotes have $80 \mathrm{~S}$ ribosomes, each consisting of a small $(40 \mathrm{~S})$ and large $(60 \mathrm{~S})$ subunit. The large subunit is composed of a 5 S RNA (120 nucleotides), a 28 S RNA (4700 nucleotides), a $5.8 \mathrm{~S}$ subunit (160 nucleotides) and approximately 49 proteins. The $40 \mathrm{~S}$ subunit has a $18 \mathrm{~S}$ RNA (1900 nucleotide) and approximately 33 proteins.

The biogenesis of the ribosome machinery is a highly coordinated process. It is composed of the synthesis and processing of ribosomal RNA (28SRNA, 18SRNA and 5.8SRNA in the nucleolus and 5SRNA in the nucleoplasm), synthesis of ribosomal proteins in the cytoplasm and their import into the nucleus, assembly of rRNA and ribosomal proteins in the nucleoplasm and finally transport of the mature subunits (40 S and $60 \mathrm{~S}$ ) into the cytoplasm.

The basic translation machinery is composed of ribosomal subunits, mRNAs, transfer RNAs (tRNAs), and translational initiation and elongation factors. First, the initiation factors eIF2, eIF3, tRNA and GTP are incorporated into a

\footnotetext{
* Correspondence: amit.verma@einstein.yu.edu

Albert Einstein College of Medicine, 1300 Morris Park Avenue, Bronx, NY 10467, USA
}

(c) 2012 Shenoy et al.; licensee BioMed Central Ltd. This is an Open Access article distributed under the terms of the Creative Commons Attribution License (http://creativecommons.org/licenses/by/2.0), which permits unrestricted use, distribution, and reproduction in any medium, provided the original work is properly cited.
$40 \mathrm{~S}$ ribosomal subunit to form a $43 \mathrm{~S}$ complex. Second, eIF4E is recruited into the $43 \mathrm{~S}$ complex to form a $48 \mathrm{~S}$ complex with mRNA. Finally, a $60 \mathrm{~S}$ ribosomal subunit and the $48 \mathrm{~S}$ subunit form the final $80 \mathrm{~S}$ complex [1].

\section{Both ribosomal proteins and ribosomal RNA have important functional roles}

The relative functional significance of the rRNAs and the ribosomal proteins has been a matter of interest for many years. In the 1970s, it was generally accepted that ribosomal proteins constituted the functionally active part of the ribosome, whereas rRNA was essentially a scaffold that kept the proteins in position for optimal functioning. By the 1980s, the pendulum had swung, with ribosomal proteins thought to be the scaffolding for the rRNA. The reason for this change was the discovery of catalytic RNA and data showing the direct involvement of rRNAs in distinct ribosomal functions, for example, the Shine-Dalgarno interactions between mRNA and rRNA during initiation of bacterial protein synthesis, as well as the predominance of rRNA at the decoding and peptidyl-transferase centre (PTC) of the ribosome. The crystal structures of the ribosome confirmed this predominance of rRNA at these active 
sites, but also revealed that a number of ribosomal proteins were located in positions of functional importance, for example, RPS12 at the decoding center, RPL11 and RPL10 as components involved in translation factor binding. Over the years, specific functions of many individual ribosomal proteins were identified and currently it is accepted that both proteins and RNA are essential for the optimal functioning of the ribosome.(Wilson, D. N. and Nierhaus, K. H. 2006).

Futhermore, several ribosomal proteins have been found to have extraribosomal functions including DNA repair; autoregulation of ribosomal protein synthesis and translation and regulation of development of malignant transformation mainly through interaction with p53. In E.coli, in addition to these functions, ribosomal proteins have been found to play a role in DNA replication, transcription and RNA processing [2,3]. The involvement of these extraribosomal functions in the pathogenesis of ribosomopathies and cancer is reviewed in this article.

\section{Mutations or deletions of ribosomal proteins can result in ribosomopathies (summarized in Table 1)}

Ribosomopathies are disorders resulting from impaired ribosome biogenesis and function. Diamond-Blackfan anemia and 5q- syndrome are the two clinical syndromes for which there is abundant genetic and experimental evidence that the impairment in erythropoiesis is due to mutations in ribosomal genes. However, there are a few other clinical syndromes in which ribosome dysfunction is thought to play a role and recently, ribosomal dysfunctions have been identified in some malignancies as well.

1. Diamond-blackfan anemia (DBA):

DBA is a congenital aregenerative anemia accompanied by erythroblastopenia (less than $5 \%$ of nucleated cells in the bone marrow are erythroblasts). It is often discovered before the age of two years. There are associated developmental malformations in $40 \%$ of the cases. The malformations most often involve the head and neck (palatine cleft, ogival palate, webbed appearance of the neck, microphthalmia, absent lower eyelashes, deformed external ears, micrognathia), limbs (triphalangeal thumb, supernumerary digits, syndactyly), urogenital tract, heart and/or the spinal cord.

In 1999, Draptchinskaia reported mutations in the gene encoding ribosomal protein S19 in patients with Diamond-Blackfan anemia [4]. Since then, mutations in a number of ribosomal proteins have been identified in 50\% of DBA patients. Mutations in RPS19 and RPS 24, which were the first two mutations identified, were shown to impair the preRNA processing of $18 \mathrm{~S}$ RNA which in turn lead to reduced production of $40 \mathrm{~S}$ ribosomal subunit and mature $80 \mathrm{~S}$ ribosomes [5-7]. The other ribosomal protein gene mutations found in DBA involve RPS7, RPS15, RPS17, RPS27A, RPL5, RPL11, RPL35A and RPL36 [8-10].

Table 1 Salient features of various ribosomopathies

\begin{tabular}{|c|c|c|c|}
\hline SYNDROME & GENE INVOLVED & CLINICAL FEATURES & LABORATORY FEATURES \\
\hline $\begin{array}{l}\text { DIAMOND } \\
\text { BLACK- FAN } \\
\text { ANEMIA }\end{array}$ & $\begin{array}{l}\text { RPS } 19 \text { (25\%); RPS 24; } \\
\text { RPS 17; RPL35A; RPL5; } \\
\text { RPL11; RPS 10; RPS } 26\end{array}$ & $\begin{array}{l}\text { Craniofacial defects; pallor; } \\
\text { short stature; thumb abnormalities }\end{array}$ & $\begin{array}{l}\text { Macrocytic anemia; elevated HbF levels; } \\
\text { elevated ADA; parvovirus B19 seropositivity } \\
(50 \% \text { by age } 15)\end{array}$ \\
\hline $\begin{array}{l}\text { SHWACHMAN } \\
\text { DIAMOND } \\
\text { SYNDROME }\end{array}$ & SBDS 7q11. 21 (90\%) & $\begin{array}{l}\text { Recurrent infections; pancreatic } \\
\text { insufficiency; short stature; increased } \\
\text { risk of malignancy (AML, MDS); } \\
\text { increased risk of CVID }\end{array}$ & $\begin{array}{l}\text { Neutropenia; thrombocytopenia; } \\
\text { aplastic anemia; neutrophil chemotaxis defect; } \\
\text { low immunoglobulins; low B cells }\end{array}$ \\
\hline $\begin{array}{l}\text { CARTILAGE } \\
\text { HAIR } \\
\text { HYPOPLASIA }\end{array}$ & $\begin{array}{l}\text { RMRP (RNase } \\
\text { Mitochondroal RNA } \\
\text { processing) gene }\end{array}$ & $\begin{array}{l}\text { Short limbed dwarfism; metaphyseal } \\
\text { chondrodysplasia; hypoplastic hair; } \\
\text { recurrent infectiions (Pneumocystis, CMV) }\end{array}$ & $\begin{array}{l}\text { Neutropenia; lymphopenia; } \\
\text { hypogammaglobulinemia; defective B cells; } \\
\text { reduced T cell count }\end{array}$ \\
\hline $\begin{array}{l}\text { TREACHER COLLINS } \\
\text { SYNDROME }\end{array}$ & $\begin{array}{l}\text { TREACLE GENE } \\
\text { (TCOF1 mutations) }\end{array}$ & $\begin{array}{l}\text { Craniofacial abnormalities (micrognathia, } \\
\text { ear deformities, macrostomia, } \\
\text { hearing loss, anti-mongoloid slant) }\end{array}$ & $\begin{array}{l}\text { Anemia; T cell abnormalities; } \\
\text { hypogammaglobulinemia }\end{array}$ \\
\hline $\begin{array}{l}\text { DYSKERATOSIS } \\
\text { CONGENITA }\end{array}$ & DKC1 at chr.X q28 & $\begin{array}{l}\text { Nail dystrophy; reticulated skin } \\
\text { pigmentation; oral leukoplakia; } \\
\text { infections; liver, lung fibrosis }\end{array}$ & $\begin{array}{l}\text { Reduced telomere length; } \\
\text { low IgM and B cell count }\end{array}$ \\
\hline 5q- SYNDROME & RPS14 & Pallor; progression to AML (10\%) & Macrocytic anemia \\
\hline TURNER SYNDROME & $\begin{array}{l}\text { HAPLOINSUFFICIENCY } \\
\text { OF RPS4X HYPOTHESIS }\end{array}$ & $\begin{array}{l}\text { Short stature; webbed neck; gonadal } \\
\text { dysgenesis; mental retardation; } \\
\text { CVS malformations }\end{array}$ & $\begin{array}{l}\text { 45XO karyotype; hypogammaglobulinemia; } \\
\text { low T cell count; CVID }\end{array}$ \\
\hline
\end{tabular}


Current therapy for DBA includes steroids and chronic blood transfusions, with the only definitive therapy being bone marrow transplantation [11].

2. 5q- syndrome:

$5 \mathrm{q}$ - syndrome is a disorder resulting from deletion of the long arm of chromosome 5 and is characterized by macrocytic anemia with normal/ elevated platelets with hypolobulated micromegakaryocytes. It is found predominantly in females of advanced age. It is now classified as an independent subtype of MDS, with better prognosis and a relatively low rate (10\%) of progression to acute myeloid leukemia compared with other subtypes of MDS [12].

In patients with $5 \mathrm{q}$ - syndrome, 1 allele of RPS14 is deleted and haploinsufficient expression of RPS14 has been found in patients $[5,13,14]$. Decreased expression of RPS14 causes ineffective erythropoiesis. It has also been shown that reexpression of RPS14 in samples from patients with 5q- syndrome rescues erythropoiesis. As discussed earlier, RPS14 deficiency causes impaired processing of 18 S RNA and in turn leads to reduced levels of the $40 \mathrm{~S}$ subunit [15]. The heterozygous deletions of chromosome $5 \mathrm{q}$ are large and haploinsufficiency of other genes may also contribute to the 5qphenotype [16]. For example, haploinsufficiency of micrornas, miR-145 and miR-146a, may be responsible for thrombocytosis seen in this disorder $[17,18]$. However, the erythroid defect, which is the aspect of the phenotype most analogous to DBA, has been shown both in in-vivo (murine) and invitro models to be a result of haploinsufficiency of RPS14 $[15,19]$.

Lenalidomide has been shown to be very effective in the treatment of patients with 5q- syndrome. In a phase 2 trial in low risk MDS patients with 5q deletions, lenalidomide decreased transfusion requirements in $76 \%$ and $61 \%$ had a complete cytogenetic response $[20,21]$.

3. Treacher collins syndrome (TCS): Also called mandibulofacial dysostosis, TCS is a rare autosomal dominant congenital disorder characterized by craniofacial abnormalities such as micrognathia, malformed or absent external ears, underdeveloped zygoma, downward slanting eyes, conductive hearing loss, colobomata of the lower eye lids, cleft palate, brachycephaly, variable degree of facial nerve involvement [22]. Intelligence of patients with TCS is usually normal but psychosocial problems associated with the facial deformity affect the quality of life of a number of patients. In 1996, TCOF1 gene mutation was found to be the cause for TCS. TCOF1 encodes a protein called
Treacle, which is a constituent of one of the preribosomal ribonucleoprotein complexes [23]. It has been shown to be essential for the transcription of ribosomal DNA and it may also be involved in the methylation of rRNA [24]. Mice haploinsufficient for TCOF1 have diminished production of ribosomes and this has been shown to correlate with decreased production of neural crest precursor cells [25]. This in turn leads to decreased number of neural crest cells migrating to the first and second pharyngeal arches, resulting in the development of the syndrome. An interesting study by Jones et al. showed that chemical and genetic inhibition of p53 in these mice could prevent the development of craniofacial abnormalities [26]. The link between ribosomopathies and p53 activation will be discussed later in the review.

4. Cartilage hair hypoplasia:

$\mathrm{CHH}$ is an autosomal recessive disorder that results in short limb dwarfism [27]. It is associated with $\mathrm{T}$ cell and B cell immunodeficiency. Hematologic abnormalities can also include macrocytic anemia, apart from lymphopenia. Management is supportive, with stem cell transplantation being the only curative option. It is indicated specially in patients with severe $\mathrm{T}$ cell deficiency, although transplantation does not cure skeletal abnormalities [28].

The genetic defect in cartilage hair hypoplasia has been identified as a mutation in the gene for RMRP, mapped to 9p12 [29]. RMRP is a ribonucleoprotein present in the nucleus and mitochondria. RMRP is involved in the cleavage of RNA in mitochondrial DNA synthesis and cleavage of pre-ribosomal RNA (pre-RNA) [30]. RMRP is required for cell growth, consistent with observations that a generalized defect in cell growth is seen in T cells, B cells and fibroblasts. In 2005, a study reported that $\mathrm{CHH}$ cells with RMRP mutation were found to have increased levels of cyclin B2 mRNA [31]. Cyclin B2 is known to contribute to chromosomal instability through alterations of the mitotic spindle checkpoint, which suggests another explanation for the bone marrow dysfunction [32].

5. Shwachman diamond syndrome (SDS): SDS is a rare autosomal recessive disorder characterized by exocrine pancreatic insufficiency, bone marrow dysfunction, skeletal abnormalities and a predisposition to leukemia [33]. It is the third most common inherited bone marrow failure syndrome after Fanconi anemia and Diamond Blackfan anemia. Patients typically present in early infancy with malabsorption, steatorrhea, failure to thrive and deficiency of Vitamins A, D, E and K. Neutropenia is the most common hematologic 
abnormality seen in patients. Data from a large international cohort study consisting of 88 patients showed neutropenia in $98 \%$ of the patients, anemia in $42 \%$, thrombocytopenia in $34 \%$ and pancytopenia in $19 \%$.

In 2003, Boocock et al. reported causal mutations in the SBDS gene, named after Shwachman-BodianDiamond, who first reported the syndrome. About $90 \%$ of the patients were found to have biallelic mutations of the SBDS gene [34]. Although the precise function of the gene is unclear, there is evidence suggesting a role in ribosome biogenesis and ribosome processing [35]. SDS cells have been shown to underexpress many ribosomal protein genes including RPS9, RPS20, RPL6, RPL15, RPL22, RPL23 and RPL29 and genes involved in rRNA and mRNA processing [36]. SBDS functions in ribosome synthesis by promoting the recycling of eukaryotic initiation factor 6 (eIF6) in a GTP-dependent manner. Finch et al. stated that a perturbation in this function causes SBDS [37]. However, SBDS is a multifunctional protein and it is also possible that non ribosomal mechanisms have a dominant role in the pathogenesis of the syndrome. Of note is SBDS' role in stabilizing the mitotic spindle [38], the absence of which may lead to chromosomal instability and therefore bone marrow failure.

6. Dyskeratosis congenita (DKC):

DKC is a rare, progressive bone marrow failure syndrome characterized by the triad of reticulated skin hyperpigmentation, nail dystrophy and oral leukoplakia. Early mortality is often associated with bone marrow failure, infections, fatal pulmonary complications or malignancy [39].

In all cases of DKC, the causative mutations are in the telomerase complex, composed of telomerase reverse transcriptase (TERT), telomerase RNA (TERC) and dyskerin, which adds specific DNA sequences to the ends of chromosomes and counters some of the normal shortening that occurs during DNA replication [40]. In X-linked recessive DKC, which has a more severe phenotype compared to the autosomal dominant DKC, the mutation occurs in the DKC1 gene, which codes for dyskerin [41]. Apart from being a part of the telomerase complex, dyskerin is also involved in rRNA modification (pseudo-uridylation of rRNA). However, the functional consequence of the defect in pseudouridylation of rRNA remains unclear. Patients with the autosomal dominant form of DKC have mutations in TERC; and two families with the autosomal recessive form of DKC have mutations in TERT which suggest that a defect in telomerase activity alone is sufficient for defective hematopoiesis
[42]. However, a study on a DKC1 mutant mouse showed pseudouridylation of rRNA before the manifestation of clinical features of DKC whereas the reduction in telomere length became evident only in the later generations [43]. This suggests that in addition to the telomerase complex mutations, defects in rRNA modification might have a contributory role in the clinical manifestations of DKC.

7. Common variable immunodeficiency (CVID): CVID is a disorder that involves low levels of most or all of the immunoglobulin classes, a lack of B lymphocytes or plasma cells that are capable of producing antibodies and frequent bacterial infections. A diagnosis of CVID is reserved for those with an undefined B cell dysfunction. About $50 \%$ of the patients also have $\mathrm{T}$ lymphocyte dysfunction. The recognition of a patient with DBA who subsequently developed CVID and the finding of a mutation in the SBDS gene in another patient with CVID has led to the hypothesis that ribosome biogenesis defects are also responsible for a subset of CVID. A review of the literature shows that patients with ribosomal defects may share abnormalities of $\mathrm{T}$ and $B$ cell development with many features of CVID, and which may not be recognized as such by non-immunologists [44].

8. Turner syndrome:

Turner syndrome results from a chromosomal abnormality in which all or part of one of the female sex chromosomes is absent. Monosomy X in which an entire $\mathrm{X}$ chromosome is missing, is most common. Characteristic physical abnormalities include short stature, webbed neck, broad chest, low hairline, low-set ears and edema. Girls with Turner Syndrome typically experience gonadal dysfunction resulting in amenorrhea and sterility. Other health problems frequently present include congenital heart disease, hypothyroidism, diabetes, vision and hearing problems, autoimmune diseases and developmental delays.

Human sex linked genes RPS4X and RPS4Y encode 2 isoforms of ribosomal protein S4. RPS4 is a component of $40 \mathrm{~S}$ subunit and haploinsufficiency of RPS4 is hypothesized to lead to some features of Turner's syndrome such as panhypogammaglobulinemia, low IgM, decreased $\mathrm{T}$ and $B$ cell numbers $[45,46]$.

\section{Ribosomal protein disorders associated with malignancies}

\section{HEPATOCELLULAR CANCER: Increased} expression of ribosomal protein S2 was found in mouse hepatocellular carcinoma (HCC) samples and in mouse livers after partial hepatectomy. RPS2 is 
involved in amino-acyl tRNA binding to ribosome, thus potentially affecting the fidelity of mRNA translation. Increased levels of RPS2 were shown to correlate with increased cell proliferation. However, whether the overexpression of RPS2 is a causative factor or just an associated phenomena in increased cell proliferation is unclear [47]. Similarly, enhanced expression of S8, L12, L23a, L27 and L30 ribosomal protein mRNAs were found in three human $\mathrm{HCC}$ cell lines (Huh-7, Hep G2 and HLF) [48]. Recently, RPL36 was found to be expressed in 45 of 60 HCC patients by immunohistochemistry. Expression of RPL36 was found to be higher in the early tumor stages (I, II). Patients with RPL36 expression revealed better overall survival $(\mathrm{p}=0.037)$ and by multivariate survival analysis, it was found to be an independent prognostic factor for overall survival $(p=0.026)$ in resected HCC. Thus, RPL36 may be involved in the early stage of hepatocarcinogenesis and could be used as a potential prognostic marker in patients with resected HCC [49].

2. Colorectal cancer: Increased expression of ribosomal protein genes, including S3, S6, S8, S12, L5 has been reported in colorectal cancer (CRC) [50]. Another study demonstrated that 12 ribosomal proteins (RPSa,S8,S11,S12,S18,S24,L7, L13a,L18,L28,L32, L35a) were differentially expressed in CRC when compared to healthy colonic mucusa.

Immunohistochemical examination of $18 \mathrm{CRC}$ and paired normal mucosa samples showed that RPS11 and RPL7 were highly expressed in CRC (especially in immature mucosal cells located in the crypt base) but could also be detected at lower levels of expression in the normal mucosa [51]. The mRNA levels for some specific ribosomal proteins were associated with the Dukes' stage of the tumor [52]. Most of the studies have been descriptive studies that do not implicate these proteins in carcinogenesis in any functional analysis.

3. Prostate cancer : The RPL19 gene has been found to be highly overexpressed in prostate cancer cell line. An inverse relationship between RPL19 expression and patient survival has been found, with patients expressing low levels of RPL19 surviving significantly longer. The statistical significance was also comparable to the Gleason score $(\mathrm{p}<0.05)$ suggesting that RPL19 could be used as an independent prognostic marker [53]. Furthermore, siRNA knockdown of RPL19 gene abrogated the aggressive phenotype of human prostate cancer [54]. Recently, the RPS2 protein was reported to be a novel therapeutic target in prostate cancer. A 'ribozyme-like' DNAZYM-1P '10-23' motif oligonucleotide was developed to knock down RPS2 expression in malignant cells and results showed that DNAZYM-1P inhibited cell growth and induced apoptosis in malignant prostate cell lines and had little effect on the normal cell lines. It was the first time that therapeutic targeting of a ribosomal protein was shown to have excellent results in pre-clinical tumour modelling studies [55].

4. Malignant melanoma : A single chain ribosome inactivating protein (scRIP), developed from the cytotoxic A subunit of Shiga- like Toxin 1 (SLT-1A), has been shown to have the ability to kill 7 of 8 melanoma cell lines. The protein called SLT-1A ${ }_{\text {IYSNKLM }}$ harbors the 7 amino acid peptide insertion IYSNKLM, allowing it to selectively attack the melanoma cells and spare normal cells. In the same study it was shown that mice with the human melanoma xenograft had better survival and tumor regression with a combination of SLT-1A ${ }^{\text {IYSNKLM }}$ and Dacarbazine than either alone [56].

5. Metastatic sarcoma : The serine/threonine kinase, mammalian target of rapamycin (mTOR), is a protein kinase of the phosphatidylinositol 3-kinase (PI3K)/AKT signaling pathway thought to have a key role in controlling cancer growth and thus is an important target for cancer therapy. Several inhibitors of mTOR are in clinical trials, including AP23573, which is being tested on metastatic sarcomas and other tumors. Phosphorylated S6 ribosomal protein is a marker for the activity of mTOR and it was found that the level of phosphorylated S6 ribosomal protein expression was predictive of early tumor response to the mTOR inhibitor. Patients with a high expression of phosphorylated S6 responded better to the mTOR inhibitors, suggesting that this is a promising predictive sarcoma marker for targeted mTOR inhibitor therapy [57].

6. Non hodgkins lymphoma: RPS6 is highly expressed in Diffuse large B cell lymphomas and genetic modulation of RPS6 protein levels with specifically targeted short hairpin RNAs (shRNA) lead to a decrease in the actively proliferating population of cells compared with control shRNA. RPS6 was shown to associate with multiple mRNAs containing a 5'TOP tract, which encode the translation machinery [58].

\section{Functional relevance of ribosomal proteins in tumorigensis}

1. Protein biosynthesis function of ribosomal proteins in cancer: Both tumor suppressors and oncogenes have been shown to modulate the ribosome protein biosynthesis as well as ribosome translation 
initiation in various models [59].. MYC, a protooncogene product, regulates the mature ribosome biogenesis by modifying the genes of necessary factors involved in ribosomal assembly. Its overexpression in tumor cells increases the expression and activity of ribosomal components. Therefore, regulation of protein synthesis could be an important mechanism by which MYC regulates cell growth and initiates tumorigenesis [60]. PTEN, a tumor suppressor, also regulates the mature ribosome formation, by suppressing the activity of RPS6K [61]. These data suggest that perturbation in the protein biosynthesis fuction of ribosomal proteins may be an important contributor to carcinogenesis.

2. Interaction of $\mathrm{p} 53$ with ribosomal proteins: Likely mechanism involved in some features of ribosomopathies and associations between ribosomal proteins and cancer.

A number of events, including haploinsufficiency of some ribosomal proteins, impart instability to ribosomal biogenesis and cause nucleolar stress. In response to this stress, some ribosomal proteins (RPL5, RPL11, RPL23, RPS7 and RPL26) bind to MDM2 and block MDM2-mediated p53 ubiquitination and degradation, resulting in p53dependent cell cycle arrest. By doing so, the ribosomal proteins play a crucial role in connecting deregulated cell growth with inhibition of cell division. The ribosomal protein-MDM2-p53 signalling pathway provides a molecular switch that may constitute a surveillance network monitoring the integrity of ribosomal biogenesis [62]. (Figure 1) In the Rps19 mutant mouse model used to study DBA, induction of p53 and p53 target genes was identified with the mutation. These mice had decreased hematocrit and increased MCV and phenocopied the human disease. The anemia observed in these mice was partially abrogated with monoallelic inactivation of p53. Homozygous inactivation of p53 in Rps19 mutant mice fully corrected the hematologic abnormality [63]. Furthermore, when the mice with the conditional deletion of a set of genes found in the common deleted region of the $5 \mathrm{q}$ - syndrome were crossed with p53 null mice, there was a complete rescue of the erythroid phenotype [19]. These findings indicate that p53 induction is critical for the macrocytic anemia caused by ribosomal dysfunction. P53 activation can also mediate tumor cytotoxicity mediated by reduction in levels of certain ribosome proteins. Decreased levels of RPS9 lead to growth inhibition in osteosarcoma cell lines. It has been shown that depletion of RPS9 provokes a rapid loss of the nucleolar protein pool, impaired production of mature $18 \mathrm{~S}$ ribosomal RNA and activation of the p53 tumor suppressor pathway. The combination of a defective ribosome biogenesis pathway and p53 activation results in unexpectedly strong antiproliferative responses in human tumor cell lines [64].

While decreased expression of some ribosomal proteins can activate p53 as part of a cellular stress response, it is also evident that some other

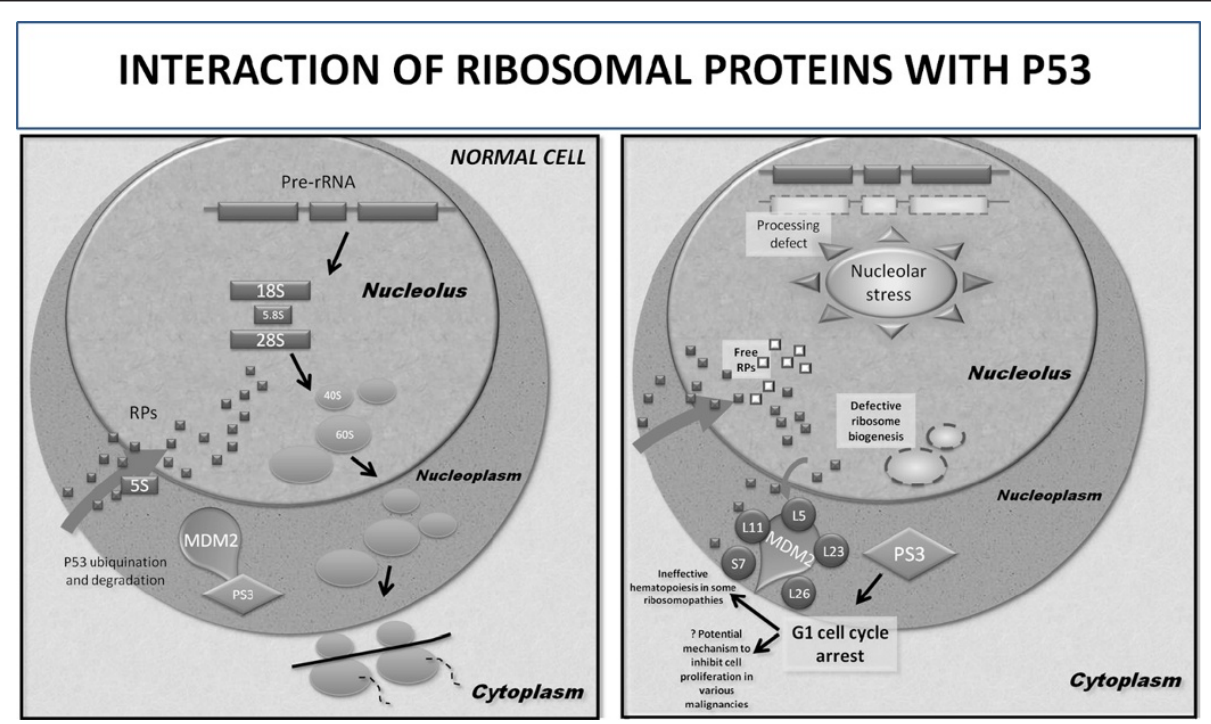

Figure 1 Loss of ribosomal proteins activats p53: In a normal cell, MDM2 binds to p53 in the nucleoplasm, leading to p53 ubiquination and degradation. Defective ribosome biogenesis leads free ribosomal proteins moving out of the nucleolus and binding MDM2, thereby preventing the degradation of 553 which then causes $\mathrm{G} 1$ cell cycle arrest. 
ribosomal proteins have direct and more specific roles in $p 53$ mRNA translation. Haploinsufficiency of a subset of r-proteins (L35, S15a, S8, L36, L7, S7, L13, S29, L23a) in zebrafish is linked to the development of malignant peripheral nerve sheath tumors. Interestingly, these nerve sheath tumors fail to produce p53 protein, despite presence of $p 53$ mRNA [65]. Moreover, RPL26 plays a role in enhancing $p 53$ mRNA translation during the DNA damage response by direct interactions with both MDM2 protein and $p 53$ mRNA [66].

Hence, ribosomal proteins have more dynamic roles in regulating the p53 tumor suppressor pathway than was previously thought and this complex interaction appears to be the most significant extraribosomal function of the ribosomal proteins, through which they exert an effect on the cell cycle and apoptosis. It could explain not only some features of ribosomopathies (particularly DBA and 5q- syndrome) but may also have a significant role in carcinogenesis (as elicited in the RPS9 silencing study).

3. Non p53 mediated extraribosomal functions of ribosomal proteins in cancer:

There is some evidence showing that other extraribosomal function of ribosomal proteins may also be directly involved in tumorigenesis. RPs can directly regulate the affect of oncogene and tumor suppressors on DNA replication, transcription and translation. The recombination of human trk protooncogene with RPL7a activates its oncogenic function [67]. RPS29, whose mRNAs is much higher in quiescent cells than that in growth phase of endothelial cells, has tumor suppressor activity for ras transformed NIH3T3 cells [68]. On the other hand, the overexpression of RPS3a gene has been shown to promote tumorigenesis in nude mice works via suppression of apoptosis by inducing synthesis of anti-apoptosis proteins [69]. These studies indicate that extraribosomal functions of distinct ribosomal proteins may also regulate tumorigenesis.

\section{Conclusions}

Ribosomal protein dysfunction has been shown to be associated with the haematological manifestations of Diamond Blackfan Anemia, 5q- syndrome and facial features of Treacher-Collins syndrome (and possibly that of DBA as the facial features of the two conditions are very similar). Interestingly, all these features have been shown to be caused by a deranged RP-MDM2-p53 pathway. Development of therapeutic targets against this pathway could possibly reverse the hematological manifestations. In Cartilage Hair Hypoplasia, Shwachman Diamond syndrome and Dyskeratosis Congenita, although there are significant ribosomal dysfunctions found, there still remains a small doubt whether they are causally associated with the conditions, particularly given the fact that the genes involved have other functions, which could also explain the clinical manifestations.

Ribosomal protein disorders in malignancies seem to be more complex. Perturbation in extraribosomal functions of ribosomal proteins seems to be directly involved in tumorigenesis and deranged ribosomal function seems to be the consequence or an associated feature. While some ribosomal proteins have been shown to exert a direct effect on proto-oncogenes and tumorigenesis, others interact directly or indirectly with the p53 tumor suppressor pathway. Further mechanistic studies will reveal distinct sets of ribosomal proteins that are deranged in specific malignancies and will potentially uncover newer therapeutic targets.

\section{Competing interests}

We have no competing interests.

\section{Authors' contributions}

NS wrote the article, RK, TB, SB, YY performed literature search and contributed to the text, AV wrote the article. All authors have read and approved the final manuscript.

Received: 23 April 2012 Accepted: 18 June 2012

Published: 18 June 2012

\section{References}

1. van Riggelen J, Yetil A, Felsher DW: MYC as a regulator of ribosome biogenesis and protein synthesis. Nat Rev Cancer 2010, 10:301-309.

2. Wool IG: Extraribosomal functions of ribosomal proteins. Trends Biochem Sci 1996, 21:164-165.

3. Warner JR, McIntosh KB: How common are extraribosomal functions of ribosomal proteins? Mol Cell 2009, 34:3-11.

4. Draptchinskaia N, Gustavsson P, Andersson B, Pettersson M, Willig TN, Dianzani I, Ball S, Tchernia G, Klar J, Matsson H, et al: The gene encoding ribosomal protein $\mathrm{S} 19$ is mutated in Diamond-Blackfan anaemia. Nat Genet 1999, 21:169-175.

5. Choesmel V, Bacqueville D, Rouquette J, Noaillac-Depeyre J, Fribourg S, Cretien A, Leblanc T, Tchernia G, Da Costa L, Gleizes PE: Impaired ribosome biogenesis in Diamond-Blackfan anemia. Blood 2007, 109:1275-1283.

6. Flygare J, Aspesi A, Bailey JC, Miyake K, Caffrey JM, Karlsson S, Ellis SR: Human RPS19, the gene mutated in Diamond-Blackfan anemia, encodes a ribosomal protein required for the maturation of $40 \mathrm{~S}$ ribosomal subunits. Blood 2007, 109:980-986.

7. Choesmel V, Fribourg S, Aguissa-Toure AH, Pinaud N, Legrand P, Gazda HT Gleizes PE: Mutation of ribosomal protein RPS24 in Diamond-Blackfan anemia results in a ribosome biogenesis disorder. Hum Mol Genet 2008, 17:1253-1263.

8. Cmejla R, Cmejlova J, Handrkova H, Petrak J, Pospisilova D: Ribosomal protein S17 gene (RPS17) is mutated in Diamond-Blackfan anemia. Hum Mutat 2007, 28:1178-1182.

9. Farrar JE, Nater M, Caywood E, McDevitt MA, Kowalski J, Takemoto CM, Talbot CC Jr, Meltzer P, Esposito D, Beggs AH, et al: Abnormalities of the large ribosomal subunit protein, Rpl35a, in Diamond-Blackfan anemia. Blood 2008, 112:1582-1592.

10. Gazda HT, Sheen MR, Vlachos A, Choesmel V, O'Donohue MF, Schneider H, Darras N, Hasman C, Sieff CA, Newburger PE, et al: Ribosomal protein L5 and L11 mutations are associated with cleft palate and abnormal thumbs in Diamond-Blackfan anemia patients. Am J Hum Genet 2008, 83:769-780

11. Vlachos A, Federman N, Reyes-Haley C, Abramson J, Lipton JM: Hematopoietic stem cell transplantation for Diamond Blackfan anemia: a 
report from the Diamond Blackfan Anemia Registry. Bone Marrow Transplant 2001, 27:381-386.

12. Vardiman JW, Harris NL, Brunning RD: The World Health Organization (WHO) classification of the myeloid neoplasms. Blood 2002, 100:2292-2302.

13. Pellagatti A, Hellstrom-Lindberg E, Giagounidis A, Perry J, Malcovati L, Della Porta MG, Jadersten M, Killick S, Fidler C, Cazzola M, et al: Haploinsufficiency of RPS14 in 5q- syndrome is associated with deregulation of ribosomal- and translation-related genes. $\mathrm{Br} J$ Haematol 2008, 142:57-64

14. Sugimoto $Y$, Sekeres MA, Makishima $H$, Traina $F$, Visconte $V$, Jankowska $A$, Jerez A, Szpurka H, O'Keefe CL, Guinta K, et al: Cytogenetic and molecular predictors of response in patients with myeloid malignancies without del[5q] treated with lenalidomide. J Hematol Oncol 2012, 5:4.

15. Ebert BL, Pretz J, Bosco J, Chang CY, Tamayo P, Galili N, Raza A, Root DE, Attar E, Ellis SR, et al: Identification of RPS14 as a 5q- syndrome gene by RNA interference screen. Nature 2008, 451:335-339.

16. Ebert BL: Deletion $5 q$ in myelodysplastic syndrome: a paradigm for the study of hemizygous deletions in cancer. Leukemia 2009, 23:1252-1256.

17. Starczynowski DT, Kuchenbauer F, Argiropoulos B, Sung S, Morin R, Muranyi A, Hirst M, Hogge D, Marra M, Wells RA, et al: Identification of miR-145 and miR-146a as mediators of the 5q- syndrome phenotype. Nat Med 2010, 16:49-58.

18. Kumar MS, Narla A, Nonami A, Mullally A, Dimitrova N, Ball B, McAuley JR, Poveromo L, Kutok JL, Galili N, et al: Coordinate loss of a microRNA and protein-coding gene cooperate in the pathogenesis of $5 q$ - syndrome. Blood 2011, 118:4666-4673

19. Barlow JL, Drynan LF, Hewett DR, Holmes LR, Lorenzo-Abalde S, Lane AL, Jolin HE, Pannell R, Middleton AJ, Wong SH, et al: A p53-dependent mechanism underlies macrocytic anemia in a mouse model of human 5q- syndrome. Nat Med 2010, 16:59-66.

20. List A, Dewald G, Bennett J, Giagounidis A, Raza A, Feldman E, Powell B, Greenberg $P$, Thomas D, Stone $R$, et al: Lenalidomide in the myelodysplastic syndrome with chromosome $5 q$ deletion. $N$ Engl J Med 2006, 355:1456-1465.

21. Melchert $M$, Kale $V$, List $A$ : The role of lenalidomide in the treatment of patients with chromosome $5 q$ deletion and other myelodysplastic syndromes. Curr Opin Hematol 2007, 14:123-129.

22. Fazen LE, Elmore J, Nadler HL: Mandibulo-facial dysostosis. (Treacher-Collins syndrome). Am J Dis Child 1967, 113:405-410.

23. Positional cloning of a gene involved in the pathogenesis of Treacher Collins syndrome. The Treacher Collins Syndrome Collaborative Group. Nat Genet 1996, 12:130-136.

24. Valdez BC, Henning D, So RB, Dixon J, Dixon MJ: The Treacher Collins syndrome (TCOF1) gene product is involved in ribosomal DNA gene transcription by interacting with upstream binding factor. Proc Natl Acad Sci U S A 2004, 101:10709-10714.

25. Dixon J, Jones NC, Sandell LL, Jayasinghe SM, Crane J, Rey JP, Dixon MJ, Trainor PA: Tcof1/Treacle is required for neural crest cell formation and proliferation deficiencies that cause craniofacial abnormalities. Proc Natl Acad Sci U S A 2006, 103:13403-13408.

26. Jones NC, Lynn ML, Gaudenz K, Sakai D, Aoto K, Rey JP, Glynn EF, Ellington $L$, Du C, Dixon J, et al: Prevention of the neurocristopathy Treacher Collins syndrome through inhibition of p53 function. Nat Med 2008 , 14:125-133.

27. McKusick VA, Eldridge R, Hostetler JA, Ruangwit U, Egeland JA: Dwarfism in the amish. II. Cartilage-hair hypoplasia. Bull Johns Hopkins Hosp 1965 116:285-326.

28. Berthet F, Siegrist CA, Ozsahin H, Tuchschmid P, Eich G, Superti-Furga A, Seger RA: Bone marrow transplantation in cartilage-hair hypoplasia: correction of the immunodeficiency but not of the chondrodysplasia. Eur J Pediatr 1996, 155:286-290.

29. Ridanpaa M, van Eenennaam $H$, Pelin $K$, Chadwick R, Johnson C, Yuan B, vanVenrooij W, Pruijn G, Salmela R, Rockas S, et al: Mutations in the RNA component of RNase MRP cause a pleiotropic human disease, cartilage-hair hypoplasia. Cell 2001, 104:195-203.

30. Welting TJ, van Venrooij WJ, Pruijn GJ: Mutual interactions between subunits of the human RNase MRP ribonucleoprotein complex. Nucleic Acids Res 2004, 32:2138-2146.

31. Thiel CT, Horn D, Zabel B, Ekici AB, Salinas K, Gebhart E, Ruschendorf F, Sticht H, Spranger J, Muller D, et al: Severely incapacitating mutations in patients with extreme short stature identify RNA-processing endoribonuclease RMRP as an essential cell growth regulator. Am J Hum Genet 2005, 77:795-806.

32. Sarafan-Vasseur N, Lamy A, Bourguignon J, Le Pessot F, Hieter P, Sesboue R, Bastard C, Frebourg T, Flaman JM: Overexpression of B-type cyclins alters chromosomal segregation. Oncogene 2002, 21:2051-2057.

33. Shwachman H, Diamond LK, Oski FA, Khaw KT: The syndrome of pancreatic insufficiency and bone marrow dysfunction. J Pediatr 1964, 65:645-663

34. Boocock GR, Morrison JA, Popovic M, Richards N, Ellis L, Durie PR, Rommens JM: Mutations in SBDS are associated with Shwachman-Diamond syndrome. Nat Genet 2003, 33:97-101.

35. Ganapathi KA, Austin KM, Lee CS, Dias A, Malsch MM, Reed R, Shimamura A: The human Shwachman-Diamond syndrome protein, SBDS, associates with ribosomal RNA. Blood 2007, 110:1458-1465.

36. Rujkijyanont $P$, Adams SL, Beyene J, Dror Y: Bone marrow cells from patients with Shwachman-Diamond syndrome abnormally express genes involved in ribosome biogenesis and RNA processing. $\mathrm{Br} J$ Haematol 2009, 145:806-815.

37. Finch AJ, Hilcenko C, Basse N, Drynan LF, Goyenechea B, Menne TF, Gonzalez Fernandez A, Simpson P, D'Santos CS, Arends MJ, et al: Uncoupling of GTP hydrolysis from elF6 release on the ribosome causes Shwachman-Diamond syndrome. Genes Dev 2011, 25:917-929.

38. Austin KM, Gupta ML, Coats SA, Tulpule A, Mostoslavsky G, Balazs AB, Mulligan RC, Daley G, Pellman D, Shimamura A: Mitotic spindle destabilization and genomic instability in Shwachman-Diamond syndrome. J Clin Invest 2008, 118:1511-1518.

39. Jyonouchi $S$, Forbes L, Ruchelli E, Sullivan KE: Dyskeratosis congenita: a combined immunodeficiency with broad clinical spectrum-a singlecenter pediatric experience. Pediatr Allergy Immunol 2011, 22:313-319.

40. Kirwan M, Dokal I: Dyskeratosis congenita: a genetic disorder of many faces. Clin Genet 2008, 73:103-112.

41. Heiss NS, Knight SW, Vulliamy TJ, Klauck SM, Wiemann S, Mason PJ, Poustka A, Dokal I: X-linked dyskeratosis congenita is caused by mutations in a highly conserved gene with putative nucleolar functions. Nat Genet 1998, 19:32-38.

42. Marrone A, Walne A, Tamary H, Masunari $Y$, Kirwan M, Beswick R, Vulliamy $T$, Dokal I: Telomerase reverse-transcriptase homozygous mutations in autosomal recessive dyskeratosis congenita and Hoyeraal-Hreidarsson syndrome. Blood 2007, 110:4198-4205.

43. Ruggero D, Grisendi S, Piazza F, Rego E, Mari F, Rao PH, Cordon-Cardo C, Pandolfi PP: Dyskeratosis congenita and cancer in mice deficient in ribosomal RNA modification. Science 2003, 299:259-262.

44. Khan S, Pereira J, Darbyshire PJ, Holding S, Dore PC, Sewell WA, Huissoon A: Do ribosomopathies explain some cases of common variable immunodeficiency? Clin Exp Immunol 2011, 163:96-103.

45. Fisher EM, Beer-Romero P, Brown LG, Ridley A, McNeil JA, Lawrence JB, Willard HF, Bieber FR, Page DC: Homologous ribosomal protein genes on the human $X$ and $Y$ chromosomes: escape from $X$ inactivation and possible implications for Turner syndrome. Cell 1990, 63:1205-1218.

46. Watanabe $M$, Zinn AR, Page DC, Nishimoto T: Functional equivalence of human X-and Y-encoded isoforms of ribosomal protein S4 consistent with a role in Turner syndrome. Nat Genet 1993, 4:268-271.

47. Kowalczyk P, Woszczynski M, Ostrowski J: Increased expression of ribosomal protein S2 in liver tumors, posthepactomized livers, and proliferating hepatocytes in vitro. Acta Biochim Pol 2002, 49:615-624.

48. Kondoh N, Shuda M, Tanaka K, Wakatsuki T, Hada A, Yamamoto M: Enhanced expression of S8, L12, L23a, L27 and L30 ribosomal protein mRNAs in human hepatocellular carcinoma. Anticancer Res 2001, 21:2429-2433.

49. Song MJ, Jung CK, Park CH, Hur W, Choi JE, Bae SH, Choi JY, Choi SW, Han $\mathrm{NI}$, Yoon SK: RPL36 as a prognostic marker in hepatocellular carcinoma. Pathol Int 2011, 61:638-644.

50. Pogue-Geile K, Geiser JR, Shu M, Miller C, Wool IG, Meisler Al, Pipas JM: Ribosomal protein genes are overexpressed in colorectal cancer: isolation of a cDNA clone encoding the human S3 ribosomal protein. Mol Cell Biol 1991, 11:3842-3849.

51. Kasai H, Nadano D, Hidaka E, Higuchi K, Kawakubo M, Sato TA, Nakayama J: Differential expression of ribosomal proteins in human normal and neoplastic colorectum. J Histochem Cytochem 2003, 51:567-574. 
52. Lai MD, Xu J: Ribosomal proteins and colorectal cancer. Curr Genomics 2007, 8:43-49.

53. Bee A, Ke Y, Forootan S, Lin K, Beesley C, Forrest SE, Foster CS: Ribosomal protein 119 is a prognostic marker for human prostate cancer. Clin Cancer Res 2006, 12:2061-2065.

54. Bee A, Brewer D, Beesley C, Dodson A, Forootan S, Dickinson T, Gerard P, Lane B, Yao S, Cooper CS, et al: siRNA knockdown of ribosomal protein gene RPL19 abrogates the aggressive phenotype of human prostate cancer. PloS One 2011, 6:e22672.

55. Wang M, Hu Y, Stearns ME: RPS2: a novel therapeutic target in prostate cancer. J Exp Clin Cancer Res 2009, 28:6.

56. Cheung MC, Revers L, Perampalam S, Wei X, Kiarash R, Green DE, AbdulWahid A, Gariepy J: An evolved ribosome-inactivating protein targets and kills human melanoma cells in vitro and in vivo. Mol Cancer 2010, 9:28

57. Iwenofu OH, Lackman RD, Staddon AP, Goodwin DG, Haupt HM, Brooks JS: Phospho-S6 ribosomal protein: a potential new predictive sarcoma marker for targeted mTOR therapy. Mod Pathol 2008, 21:231-237.

58. Hagner PR, Mazan-Mamczarz K, Dai B, Balzer EM, Corl S, Martin SS, Zhao XF, Gartenhaus RB: Ribosomal protein $\mathrm{S} 6$ is highly expressed in non-Hodgkin lymphoma and associates with mRNA containing a 5 ' terminal oligopyrimidine tract. Oncogene 2011, 30:1531-1541.

59. Ruggero D, Pandolfi PP: Does the ribosome translate cancer? Nat Rev Cancer 2003, 3:179-192.

60. Boon $\mathrm{K}$, Caron HN, van Asperen R, Valentijn L, Hermus MC, van Sluis $\mathrm{P}$, Roobeek I, Weis I, Voute PA, Schwab M, et al: N-myc enhances the expression of a large set of genes functioning in ribosome biogenesis and protein synthesis. EMBO J 2001, 20:1383-1393.

61. Coelho CM, Kolevski B, Walker CD, Lavagi I, Shaw T, Ebert A, Leevers SJ, Marygold SJ: A genetic screen for dominant modifiers of a small-wing phenotype in Drosophila melanogaster identifies proteins involved in splicing and translation. Genetics 2005, 171:597-614.

62. Deisenroth $C$, Zhang Y: Ribosome biogenesis surveillance: probing the ribosomal protein-Mdm2-p53 pathway. Oncogene 2010, 29:4253-4260.

63. McGowan KA, Li JZ, Park CY, Beaudry V, Tabor HK, Sabnis AJ, Zhang W, Fuchs $\mathrm{H}$, de Angelis MH, Myers RM, et al: Ribosomal mutations cause p53mediated dark skin and pleiotropic effects. Nat Genet 2008, 40:963-970.

64. Lindstrom MS, Nister M: Silencing of ribosomal protein S9 elicits a multitude of cellular responses inhibiting the growth of cancer cells subsequent to p53 activation. PLoS One 2010, 5:e9578

65. Maclnnes AW, Amsterdam A, Whittaker CA, Hopkins N, Lees JA: Loss of p53 synthesis in zebrafish tumors with ribosomal protein gene mutations. Proc Natl Acad Sci U S A 2008, 105:10408-10413.

66. Takagi M, Absalon MJ, McLure KG, Kastan MB: Regulation of p53 translation and induction after DNA damage by ribosomal protein L26 and nucleolin. Cell 2005, 123:49-63.

67. Ziemiecki A, Muller RG, Fu XC, Hynes NE, Kozma S: Oncogenic activation of the human trk proto-oncogene by recombination with the ribosomal large subunit protein L7a. EMBO J 1990, 9:191-196.

68. Coppock D, Kopman C, Gudas J, Cina-Poppe DA: Regulation of the quiescence-induced genes: quiescin Q6, decorin, and ribosomal protein S29. Biochem Biophys Res Commun 2000, 269:604-610.

69. Naora H, Takai I, Adachi M: Altered cellular responses by varying expression of a ribosomal protein gene: sequential coordination of enhancement and suppression of ribosomal protein S3a gene expression induces apoptosis. J Cell Biol 1998, 141:741-753.

doi:10.1186/1756-8722-5-32

Cite this article as: Shenoy et al:: Alterations in the ribosomal machinery in cancer and hematologic disorders. Journal of Hematology \& Oncology 2012 5:32.

\section{Submit your next manuscript to BioMed Central and take full advantage of:}

- Convenient online submission

- Thorough peer review

- No space constraints or color figure charges

- Immediate publication on acceptance

- Inclusion in PubMed, CAS, Scopus and Google Scholar

- Research which is freely available for redistribution

Submit your manuscript at www.biomedcentral.com/submit
C) Biomed Central 